\title{
A COMPARATIVE STUDY OF ECONOMIC DEVELOPMENT OF GUJARAT AND KERALA (A STUDY WITH SPECIAL REFERENCE TO THE ROLE OF INFRASTRUCTURE IN ECONOMIC DEVELOPMENT)
}

\author{
Sanjeev Sushil Jha \\ Research Scholar, Jaipur National University, Jagatpura, Jaipur, India \\ Prof. Dr. J.K Tandon \\ Research Director, School of Business Management \\ Jaipur National University, Jagatpura, Jaipur, India
}

\begin{abstract}
India is considered to be one among the top 10 fastest developing countries of the globe and the growth rate of the economy has been one of the highest among the countries of the world for the last few years. The country started garnering momentum of growth after the economic reforms in 1991 which has been followed by massive investment in infrastructure building in the country by the entry of many countries and companies through FDI participation. The country is forecasted to grow at a higher rate in future also which is evidenced by the data released by international agencies such as IMF, WTO and the World Bank. The country's inclusion in trade blocks such as BRICS is an indication of its growing importance among various trading nations. The economy has been experiencing an annual average growth rate of around 6.02 percent from 1991 onwards. To maintain the tempo of growth, infrastructure development is an inevitable necessity as all the sectors of an economy depends upon the basic infrastructural framework for it smooth and efficient functioning. Even though the concept of economic development used to be measured in terms of growth of output, a real outlook about the economic progress can be assessed by measuring the growth rate in per capita output and human development index, which is very much influenced by infrastructure development. Regional development in terms of infrastructure growth in a nation like India is highly impacted by a mixed bag of multiple factors such as topographical, economic and political variables. The uneven pattern of investment in industries as well as in economic overhead like transportation and communication facilities, irrigation and power has resulted in regional disparities also in India. Kerala and Gujarat are very small regions in India; still these states are center of attention of the world's development economists due to the improvement in infrastructure facilities. The main objective of this study is to compare the growth models of both the states and
\end{abstract}


assess the role of infrastructure like transportation and power in the economic development of these states

Keyword: Infrastructure Development, Economy, Regional Development, Transportation and Power.

Cite this Article: Sanjeev Sushil Jha and Prof. Dr. J.K Tandon, A Comparative Study of Economic Development of Gujarat and Kerala (A Study with Special Reference to the Role of Infrastructure in Economic Development). Journal of Management, 6(1), 2019, pp. 39-54.

http://www.iaeme.com/jom/issues.asp?JType=JOM\&VType=6\&IType $=1$

\section{INTRODUCTION}

Provision and maintenance of sufficient infrastructure facilities are absolutely needed for an economy to achieve stability in growth which should be sustainable also. The availability of infrastructure facilities in the form of power, telecommunication and transportation is absolutely vital for the success of all other sectors of an economy, as there is a mutually interactive relationship between infrastructure and other economic activities in a country. The interactive relationship between infrastructure and economic development is not once for all affairs, but it is a continuous chain of process and economic development should be preceded, accompanied and succeeded by progress in infrastructure (Rao, 1981). Infrastructure development does leads to economic growth and affects the output significantly (Fedderke et. al 2006). Hence, well planned and well-structured infrastructure facilities in the field of healthcare, education, power supply, transport and communication, water sewage facilities etc are needed to promote productivity by synchronizing various activities in different sectors of the economy. The attainment of higher affluence and higher standard of living of the advanced countries with sound infrastructure development is a valid testimony that proves the linkage between infrastructure growth and economic development (IBRD, 2005).

The paper is an attempt to explore the impact of two vital elements of infrastructure such as power and transportation on the economic growth of a country like India by considering the infrastructure development in two states such as Kerala and Gujarat. The rationale for choosing power and transportation in this study is primarily influenced by the findings of many research studies on the relationship between energy, transportation and economic growth in developed countries (van Ruijen et al., 2008) as it is found that these elements of infrastructure played a crucial role in generating the momentum of growth through its percolation effect on the other sectors of the economy (Toman and Jemelkova, 2003). Power is a core industry for a country like India as it facilitates development across various sectors of the Indian economy, such as manufacturing, agriculture, commercial enterprises and railways. Even though India possesses the fifth largest electricity generation capacity among all countries of the world, the growth momentum initiated by various economic reforms since 1991 has boosted the demand for electricity in such a way that the current supply of power is much lower than the demand in various parts of the country. The gap between demand and supply is expected to widen in future also as the economy has gathered high pace of growth now. Another crucial element of infrastructure that is inevitable for growth of an economy is the transportation infrastructure and network because the logistics demand has been increasing throughout the country and cheapest modes of transportation is needed to reduce the cost of movement of goods. It is estimated that the Compound Annual Growth Rate (CAGR) of road length development is $3.52 \%$ during the period of 2001 to 2017 in India which is insufficient to meet the increased demand for road transport requirements. 
A comparative study of economic development of Gujarat and Kerala (A study with special reference to the role of infrastructure in economic development)

\section{REVIEW OF LITERATURE}

The approaches towards development vary from states to states in India. The common approach to economic development used by states and local self-governments are primarily focused on financial measurements and accumulation of physical assets (Thompson, 2010). In certain countries, it is measured by considering both social as well as economic indicators (Lynch, 2004). The model of growth followed by the nation as a whole in India is the synchronization of various models of growth since its independence (Nagaraj, 2012). One of the most popular growth models that are frequently compared for its uniqueness is the growth models of Gujarat and Kerala. The Kerala model is highly acclaimed by the economist Amartya Sen whereas the Gujarat model is hailed as the best model by Jagadish Bhagawati. Since 1970s onwards a number of experts and economists have opined that the state of Kerala as a 'model of development' (RatcliRe, 1978; Morris \& McAlpin, 1982; Amin, 1991; Franke \& Chasin, 1994, 1997). It is a fact that the state could achieve tremendous attention nationally as well as globally due to its achievement in social development and improvement of living conditions, in spite of low of per capita income and stagnant economic growth rates (Ramachandran, 1997).

The state of Gujarat appears to be a paradigmatic example of development since the dawn of the century. Many researchers tried to focus on different aspects of the economy of Gujarat. Kundu (2000) made an attempt to analyze the trends and patterns of urbanization in Gujarat whereas Hirway (2000) focused on a diversified economic structure and the role of government in diversification. It is observed that the state has been achieving tremendous growth in manufacturing sector by retaining the importance of the primary sector also (Bhalla \& Singh, 1997). Even though there are differences of opinion among experts relating to the effectiveness and sustainability of the models, it is an undisputed fact that infrastructure such as power and transportation plays a major role in laying the foundation of a strong base for sustainable development. A significant number of academic research papers and empirical evidences are available in economics and management literature that highlights positive causal relationship between infrastructure development and economic growth of various countries of the world including India. From the point of view of infrastructure development in various states of India, the study conducted by Ahluwalia (2007) shows a positive correlation between infrastructure spending of states and economic growth with a correlation value of 0.5. In another study conducted by Bibek Debroy and Laveesh Bhandari during 2009-12 focused on a comprehensive inter-state analysis of the effect of infrastructure development by considering its effect on economic, social and human development of various states in India. A similar line of approach was followed by Mundle et al (2012), when they studied the inter-state comparison of the performance of various Indian States in governance front with respect to infrastructure and economic growth. Of late, Shrikant Rao (2013) in their study ranked the performance of Indian states on economic freedom front in infrastructure development.

While studying the positive impact of infrastructure development among various states, Sahoo, Dash \& Nataraj, (2010) reveals that channelization of direct investment on infrastructure creates (i) production facilities and stimulates economic activities; (ii) reduces transaction costs and trade costs and (iii) provide employment opportunities to the poor. It is also found in the study that the lack of infrastructure creates bottlenecks for sustained growth and poverty reduction in various parts of the country. Even regional disparities in development of infrastructure faculties were found in the study conducted by Patra and Acharya (2011) in 16 major Indian states by using composite infrastructure development index. The infrastructure variables and its impact on growth was observed by using correlation matrix and path regression analysis and the study reveals positive correlation between infrastructure development and economic growth and negative correlation with poverty. Verhtsel et al. (2015) emphasizes coexistence of regional imbalances in relatively developed and economically depressed regions 
within many states in India and mentions that balanced regional development is necessary for the harmonious growth of federal states in India. The regional imbalances in transportation, power and communication facilities play an important role in the economic growth and regional development of many states in India.

\section{OBJECTIVE}

The objectives of the study are:

1. To explore the trend of economic growth of Gujarat and Kerala

2. To assess the link between infrastructure development and economic growth

3. To analyze the performance of transportation and power generation sectors in Kerala and Gujarat

\section{RESEARCH METHODOLOGY}

In order to study the growth models and the impact of infrastructure growth and economic development in India, two sample states are selected, such as Gujarat and Kerala. The sample states are selected as these states show relatively high growth in infrastructure building, healthcare and education. The study focuses on infrastructure growth based on transportation and power generation. The major sources are the database of the governmental agencies such as National Sample Survey Organization, Central Statistical Organization (CSO), Natioal Council of Applied Economic Research (NCAER), Ministry of Finance of Govt., of India, Kerala and Gujarat, State Planning Board of Gujarat Government and Department of Economics and Statistics. Data is also collected from leading newspapers, research journals, magazines, trade journals and websites. The performance measures of physical infrastructure both levels and trends - are chosen for the select sectors. The aspects of infrastructure covered are power and transportation.

\section{IMPACT OF INFRASTRUCTURES IN ECONOMIC DEVELOPMENT OF INDIA}

There are various definitions given to the term infrastructure in academic literature and research works. In general, it can be defined as the fundamental facilities, amenities and systems supporting a country, state, city or any other geographical area, inclusive of services and facilities inevitable for an economy to function effectively (Sullivan, Sheffrin \& Steven, 2003). These facilities and services conducive for the functioning of an economy can be broadly categorized into hard infrastructure and soft infrastructure (Yasheng, 2003). The hard infrastructure includes capital assets such as utilities, transportation, drainage system etc which provides all the physical networks that keeps an economy to function and grow effectively. The soft infrastructure is the framework needed to keep and maintain various institutions which consists of software programs, financial system, governing rules and regulations etc.

India is one among the fastest growing economies in the world and the rate of growth is expected to pick up accelerating momentum in 2019 and 2020 as it is poised to grow at a rate of 7.3\% which is much higher than economies such as China and other developing countries (World Bank, 2018). In order to maintain the tempo of growth, India needs to develop sufficient infrastructure in the form of roads, railway system, ports, airports and power generation so as to integrate the various components of growth in a cohesive way to create inclusive growth and thus enable the economy to directly link the macro and micro determinants of growth. At the same time the country should be able to integrate its activities with the external world as almost all the economies give focused attention to the development of infrastructure now (Estache \& Lewis, 2009). Thus, its linkage to the economy is broad, multiple and complex as infrastructure 
A comparative study of economic development of Gujarat and Kerala (A study with special reference to the role of infrastructure in economic development)

influences a myriad of economic activities such as production, consumption, distribution and allocation of resources in the country. Transport and power is a key infrastructure in the present study as it offers various direct and indirect benefits to the Indian economy. But in India, the level of transport infrastructure development is not so satisfactory, both in quantity and quality, in contrast to developed countries of the world. In the present study, focus is given only to the hard infrastructure variables such as power and transportation in two selected sample states in India which are Kerala and Gujarat. These states are given high ranking in many of the development parameters rated by many research agencies and government and hence, the sample is selected to make a reasonable comparison of the states on the basis of growth of GDP and PCI in comparison with the development of infrastructural facilities.

\section{MODEL OF GROWTH: GUJARAT AND KERALA}

The model of economic growth adopted by both the states is different as the Kerala Model strives to achieve economic development by activating the economy through social transformations whereas the Gujarat Model attempts to introduce social change through economic changes. In the opinion of Amartya Sen (2013), the Kerala model of growth is considered to be one of the best models on account of its impact on social development. Sen strongly believes that the investment in social infrastructure results in faster economic development through its permeating effects on capability enhancement in different sectors of the economy which is visible from the experience of Kerala. Sen criticizes Gujarat model on the basis of poor infrastructure in education, healthcare and transport system. Kerala is treated as an example of a poor state that gradually transformed into a rich state due to human capability formation and economic development.

The growth model followed by Gujarat is highly acclaimed to be the most suitable one for sustainable economic development by famous economists like Jagadish Bhagwati (2013). He is of the opinion that the Kerala model of growth is not stable as it fails to win the success test of sustainable development due to the lack of sufficient resource base and the development of social infrastructure is possible only through the development of economic infrastructure. According to Bhagwati, Kerala achieved success due to the blessings of its growth-oriented approach and not because of its superior education and health. The state started with higher social indicators as compared to the rest of the country and it has been able to maintain the tempo even now.

Table1. Comparison of GDP of Gujarat \& Kerala with All India Average

\begin{tabular}{|c|c|c|c|}
\hline Years & $\begin{array}{c}\text { GDP Growth in Gujarat } \\
\text { (Crores of Rupees) }\end{array}$ & $\begin{array}{c}\text { GDP Growth in Kerala } \\
\text { (Crores of Rupees) }\end{array}$ & $\begin{array}{c}\text { GDP Growth in India } \\
\text { (Crores of Rupees) }\end{array}$ \\
\hline 2004 & 168,080 & 96,698 & 2971464 \\
\hline 2005 & 203,373 & 119,264 & 3390503 \\
\hline 2006 & 233,776 & 131,294 & 3953276 \\
\hline 2007 & 253,393 & 141,667 & 4582086 \\
\hline 2008 & 281,273 & 154,093 & 5303567 \\
\hline 2009 & 300,341 & 162,659 & 6108903 \\
\hline 2010 & 334,127 & 177,571 & 7248860 \\
\hline
\end{tabular}


Sanjeev Sushil Jha and Prof. Dr. J.K Tandon

\begin{tabular}{|c|c|c|c|}
\hline Years & $\begin{array}{c}\text { GDP Growth in Gujarat } \\
\text { (Crores of Rupees) }\end{array}$ & $\begin{array}{c}\text { GDP Growth in Kerala } \\
\text { (Crores of Rupees) }\end{array}$ & $\begin{array}{c}\text { GDP Growth in India } \\
\text { (Crores of Rupees) }\end{array}$ \\
\hline 2011 & 367,581 & 189,851 & 8391691 \\
\hline 2012 & 392,058 & 200,958 & 9388876 \\
\hline 2013 & 416,163 & 212,860 & 10472807 \\
\hline 2014 & 443,546 & 225,354 & 11493596 \\
\hline
\end{tabular}

Source: CSO, 2015.
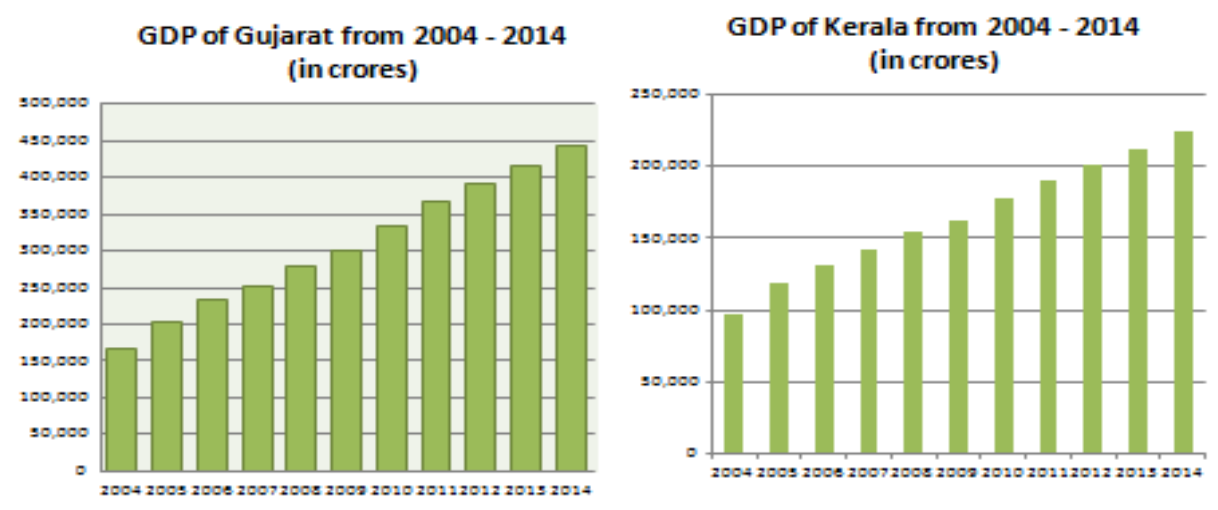

Source: Central Statistical Organization, 2015

Figure 1 GDP

Looking from the current perspective of growth achieved by both the states, it can be stated that both models have got its own advantages and disadvantages. For measuring economic development and growth, the major parameter which is given much emphasis by all the economists and experts is the Net State Domestic Product (NSDP) as well as Per Capita Net State Domestic Product (PCNSDP) of economies. Based on the NSDP and PCNSDP, both the states can be ranked as per details furnished in table 2 .

Table 2 NSDP and PCNSDP of Gujarat and Kerala State (1980-2016)

\begin{tabular}{|c|c|c|c|c|c|c|c|c|}
\hline \multirow[t]{3}{*}{ Year } & \multicolumn{4}{|c|}{ NSDP (Current Price in Crores of Rs) } & \multicolumn{4}{|c|}{ PCNSDP (Current Prices in Crores of Rs) } \\
\hline & \multicolumn{2}{|c|}{ Gujarat } & \multicolumn{2}{|c|}{ Kerala } & \multicolumn{2}{|c|}{ Gujarat } & \multicolumn{2}{|c|}{ Kerala } \\
\hline & NSDP & Ranking & NSDP & Ranking & PCNSDP & Ranking & PCNSDP & Ranking \\
\hline $1980-81$ & 7076 & 7 & 4631 & 10 & 2089 & 6 & 1835 & 7 \\
\hline $1985-86$ & 13081 & 8 & 7878 & 10 & 3468 & 6 & 2918 & 7 \\
\hline $1990-91$ & 26133 & 7 & 12173 & 11 & 6343 & 5 & 5110 & 10 \\
\hline $1995-96$ & 62017 & 6 & 35330 & 11 & 13665 & 5 & 11469 & 7 \\
\hline
\end{tabular}


A comparative study of economic development of Gujarat and Kerala (A study with special reference to the role of infrastructure in economic development)

\begin{tabular}{|c|c|c|c|c|c|c|c|c|}
\hline Year & \multicolumn{4}{|c|}{ NSDP (Current Price in Crores of Rs) } & \multicolumn{3}{c|}{ PCNSDP (Current Prices in Crores of Rs) } \\
\hline $2000-01$ & 92110 & 6 & 63094 & 10 & 19228 & 7 & 19463 & 6 \\
\hline $2005-06$ & 206440 & 4 & 120269 & 8 & 37780 & 4 & 36958 & 5 \\
\hline $2010-11$ & 454853 & 4 & 233177 & 9 & 77485 & 6 & 69943 & 8 \\
\hline$* 2015-16$ & 1029010 & - & 561546 & - & 139254 & - & 148011 & - \\
\hline
\end{tabular}

Source: Central Statistical Organization; Statistical Organization of Punjab; Economic Survey, Ministry of Finance (1980 - 2016). *2016-16 ranking not available.

The table shows that the data for 15 years related to NSDP and PCNSDP of the state of Gujarat and Kerala at current prices for a period ranging from 1980 to 2016, which is further sub-categorized into 8 different periods. From the table, it is obvious that the state of Gujarat is ranked $4^{\text {th }}$ for NSDP and $6^{\text {th }}$ for PCNSDP in the year 2010-2011. The NSDP ranking of the state has been continuously and consistently increasing during the period under study. The PCNSDP has improved to 4 th position and later regressed to $6^{\text {th }}$ position that equals to the rate of growth recorded during the period 1980-81. As far as Kerala is considered, appreciable improvement in the growth of NSDP was recorded during 2005-2006 as it could improve the position from $10^{\text {th }}$ in 1981 to $8^{\text {th }}$ in 2006 . But the figure got regressed in the year 2011 to $9^{\text {th }}$ position. Kerala could improve the per capita income during 2005-2006 and later dipped down to $8^{\text {th }}$ position in 2011. Thus, if the overall NSDP is considered, the growth rate of Gujarat has been appreciable and this achievement is the result of industrialization of the economy during this period. Gujarat could increase the NSDP by nearly more than 64 times during the period of the study whereas Kerala could achieve only an increase of 50times in its NSDP during the same period. In the case of PCNSDP, the state of Gujarat could increase the figure by 39 times during the span of 31 years whereas the corresponding figure for the state of Kerala is 38 times. Thus, even though Gujarat could achieve an increase of 64 times in its NSDP, it failed to maintain the same rate of growth in its PCNSDP. The latest figures for the period of 2016 reveals that the state of Kerala has improved much in its PCNSDP as compared to Gujarat, which has recorded remarkable growth in its NSDP during the 35 years under consideration.

The major reason for this trend of PCNSDP can be attributed to the fact that the population growth of Gujarat has been much higher as compared to Kerala during the period under study. But the figures pertaining to the period after 2011 shows that the population growth of Gujarat has been declining which is a promising sign of stable growth for the state. In the case of Kerala, the population growth has been decreasing and it is estimated that the growth becomes negative after 2020 (World Population Review, 2017). A brief comparison of population growth is furnished in table 3.

Comparison of Population Growth of both the states is given in table 3.

Table 3 Comparison of population growth

\begin{tabular}{|c|c|c|c|c|}
\hline Year & \multicolumn{2}{|c|}{ Gujarat (Population in millions) } & \multicolumn{2}{c|}{ Kerala (Population in millions) } \\
\hline & Total Population & Population Growth & Total Population & Population Growth \\
\hline 2013 & 62.70 & & 35.20 & \\
\hline 2014 & 63.90 & 1.91 & 35.70 & 1.42 \\
\hline
\end{tabular}


Sanjeev Sushil Jha and Prof. Dr. J.K Tandon

\begin{tabular}{|c|c|c|c|c|}
\hline Year & \multicolumn{2}{|c|}{ Gujarat (Population in millions) } & \multicolumn{2}{c|}{ Kerala (Population in millions) } \\
\hline 2015 & 65.20 & 2.03 & 36.00 & 0.95 \\
\hline 2016 & 66.10 & 1.38 & 36.60 & 1.65 \\
\hline 2017 & 67.16 & 1.58 & 36.96 & 0.97 \\
\hline
\end{tabular}

Source: India Population 2018 (www.indiapopulation2018.in)

The following table 4 shows the Gross Value Added (GVA) in NSDP of both the states during the year 2016, which gives a detailed overview of the sector-wise contribution towards economic growth.

Table 4 Sector-wise contribution towards GVA

\begin{tabular}{|c|c|c|c|}
\hline Sl. No. & Economic Activity & Gujarat (\%) & Kerala (\%) \\
\hline 1 & Agriculture, Forestry \& Fishing & 0.23 & -0.70 \\
\hline 2 & Mining \& Quarrying & 34.30 & 17.90 \\
\hline 3 & Manufacturing & 15.40 & -0.39 \\
\hline 4 & Power \& Utility & 6.40 & 2.60 \\
\hline 5 & Construction & 3.50 & 5.40 \\
\hline 6 & Trade, Repair \& Restaurants & 8.50 & 6.80 \\
\hline 7 & Transport, storage, communication and broadcasting & 8.40 & 8.40 \\
\hline 8 & Financial Services & 7.30 & 8.10 \\
\hline 9 & Real estate, ownership dwelling and professional services & 8.40 & 5.20 \\
\hline 10 & Other Services & 8.50 & \\
\hline
\end{tabular}

Source: Growth in Gross Value-Added Ending 2016 (Sector wise comparison), SIPI $3^{\text {rd }}$ Edition, NCAER 2017.

A sector-wise comparison of the contribution towards NSDP during 2016 shows that agriculture and allied activities (primary sector) contributes 34.53 of Gross Value Added (GVA) in the NSDP of Gujarat whereas it accounts for 17.20 to the state of Kerala. The agricultural activities show a declining trend in Kerala as more employment opportunities are created in IT sector and the wage system is such that the cost of labor is very high which makes agricultural activities less profitable. Manufacturing accounts for $15.40 \%$ to the GVA of Gujarat whereas the corresponding figure is only $5.70 \%$ for the state of Kerala. Kerala is lagging behind Gujarat in industrialization as trade union activities impede the growth of business in the state. Of late, the trend has been getting improved due to the development of tertiary sector like IT, tourism and healthcare. Power contribution is much high for the economy of Gujarat whereas is it is dismally poor in a state like Kerala. The source of power is not diversified towards profitable avenues in a state like Kerala whereas Gujarat has been proved to be a model for power generation and growth during the last two decades. 
A comparative study of economic development of Gujarat and Kerala (A study with special reference to the role of infrastructure in economic development)

\section{ROLE OF INFRASTRUCTURE: POWER \& TRANSPORTATION}

\subsection{Power Sector: Gujarat and Kerala}

India commands the fifth largest position for electricity generation in the world with a total installed capacity of 228722 MW out of which $90062 \mathrm{MW}$ is from stated owned electricity boards, 72,927 MW from privately owned companies and $65733 \mathrm{MW}$ is from central government owned utility providers (IREDA, 2018). Gujarat is clearly the power house of India with 16 per cent of India's installed capacity and highest per capital installed electricity generation. On the other hand, Kerala is one of the states in India with lowest per capital production and per capital consumption of electricity.

The table shows data related to a comparative study of installed electricity capacity in Gujarat and Kerala as on $31^{\text {st }}$ March 2015.

Table 7 Total installed electricity capacity in Kerala \& Gujarat as on 31.03.2015

\begin{tabular}{|l|l|l|l|}
\hline \multirow{2}{*}{ Fuel } & \multicolumn{3}{|l|}{ Percentage } \\
\cline { 2 - 4 } & Kerala (2836 MW) & Gujarat (40950 MW) & India (278734 MW) \\
\hline Thermal & 25.35 & 75.25 & 69.6 \\
\hline Hydro & 73.41 & 11.68 & 15.2 \\
\hline Nuclear & 0 & 1.73 & 2.1 \\
\hline Renewable resources & 1.24 & 11.34 & 13.1 \\
\hline
\end{tabular}

Source: Kerala economic review 2015 \& Socio-economic review of Gujarat, 2015

Note: Figures in brackets show total production capacity in mega watt

Kerala's power sector is being handicapped by certain serious hurdles such as inadequate production, over dependence on hydro power and less dependence on renewable resources. On the other hand, Gujarat has been able to become the highest producer of electricity by developing generation capacity relying heavily on thermal power (75.25\%). Kerala's excessive dependence on hydel power $(73.41 \%)$ evinces its necessitude of depending traditional sources of energy heavily. Declining monsoon coupled with humane and environmental problems attributed to reservoirs creates crisis in power generation from hydro-projects in Kerala and other states. The incidence and impact of these problems have heavily obstructed the production of power in Kerala where three-fourth of the power has been generated from hydel projects only. Gujarat with the commendable share of 11.34 per cent has been able to diversify its power generation capacity to the renewable resources such as wind, tidal and solar energy while mere 1.24 per cent of Kerala's installed capacity has been generated from it. Shortage of power is the prime obstacle in starting new industrial units in Kerala (KSPB, 2016).

Table 8 All India Allocated Power Capacity, 2015 for Gujarat and Kerala

\begin{tabular}{|c|c|c|c|c|c|c|c|c|c|c|}
\hline \multicolumn{11}{|c|}{ All India Allocated Power Capacity 2015} \\
\hline \multirow[b]{2}{*}{ State } & \multicolumn{4}{|c|}{ Thermal (MW) } & \multirow{2}{*}{$\begin{array}{c}\text { Nuclea } \\
\text { r } \\
\text { (MW) }\end{array}$} & \multicolumn{3}{|c|}{ Renewable (MW) } & \multirow{2}{*}{$\begin{array}{l}\text { Total } \\
\text { (MW) }\end{array}$} & \multirow{2}{*}{$\begin{array}{c}\% \text { Of } \\
\text { Nation } \\
\text { al Total }\end{array}$} \\
\hline & Coal & Gas & $\begin{array}{c}\text { Diese } \\
1\end{array}$ & $\begin{array}{c}\text { Sub } \\
\text { Total }\end{array}$ & & Hydel & Others & $\begin{array}{l}\text { Sub } \\
\text { Total }\end{array}$ & & \\
\hline $\begin{array}{l}\text { Gujara } \\
t\end{array}$ & $\begin{array}{c}16353.7 \\
2\end{array}$ & $\begin{array}{c}6806.0 \\
9\end{array}$ & & $\begin{array}{c}23159.8 \\
1\end{array}$ & 559.32 & 772.00 & $\begin{array}{c}4940.0 \\
0\end{array}$ & $\begin{array}{c}6271.3 \\
2\end{array}$ & $\begin{array}{c}29431.1 \\
3\end{array}$ & 10.66 \\
\hline Kerala & 1038.69 & 533.58 & $\begin{array}{c}234.6 \\
0\end{array}$ & 1806.87 & 228.60 & $\begin{array}{c}2100.0 \\
0\end{array}$ & 204.05 & $\begin{array}{c}2085.5 \\
5\end{array}$ & 4121.02 & 1.49 \\
\hline
\end{tabular}


Source: "Executive summary of month of November 2015": Central Electricity Authority, Ministry of Power, Government of India.

The total thermal power in MW terms for Kerala is only $7.80 \%$ of the total allocated power capacity of Gujarat in 2015 . Even though there is relatively minor difference between the states in connection with the nuclear power generation in the year 2015, it has considerably increased in its contribution towards power generation in the state of Gujarat recently (CEA, Report 2018). In the case of renewal energy, the Kerala's allocation is only $14 \%$ of that of Gujarat. The percentage of national total itself shows high disparity between the states in power allocation during 2015. Gujarat has been striving to become an industrialized state by giving incentive to companies, both global and local (ISID, 2017). This aspect points towards the fact that the state is promoting inclusive growth within the country as well as promoting investment from the rest of the world. The latest figures of total installed capacity in power stations in Gujarat and Kerala reveal the sector-wise investment in power generation.

Table 9 Total Installed Capacity (MW) in Power Stations in Gujarat and Kerala as on 31.03.2017

\begin{tabular}{|c|c|c|c|c|c|c|c|c|c|}
\hline \multirow[t]{2}{*}{ State } & \multirow[t]{2}{*}{ Sector } & \multicolumn{4}{|c|}{ Thermal } & \multirow{2}{*}{ Nuclear } & \multirow{2}{*}{ Hydro } & \multirow{2}{*}{$\begin{array}{c}\text { Renewal } \\
\text { Energy }\end{array}$} & \multirow{2}{*}{$\begin{array}{c}\text { Grand } \\
\text { Total }\end{array}$} \\
\hline & & Coal & Gas & Diesel & Total & & & & \\
\hline \multirow{4}{*}{ Gujarat } & State & 5230.00 & 2321.82 & 0.00 & 7551.82 & 0.00 & 772.00 & 8.00 & 8331.82 \\
\hline & Private & 7765.67 & 3960.00 & 0.00 & 11725.67 & 0.00 & 0.00 & 663.89 & 18389.56 \\
\hline & Central & 3012.09 & 424.00 & 0.00 & 3436.09 & 559.00 & 0.00 & 0.00 & 3995.09 \\
\hline & Subtotal & 16007.76 & 6705.82 & 0.00 & 22713.58 & 559.00 & 772.00 & 6671.89 & 30716.47 \\
\hline \multirow{4}{*}{ Kerala } & State & 0.00 & 0.00 & 159.96 & 159.96 & 0.00 & 1881.50 & 145.02 & 2186.48 \\
\hline & Private & 615.00 & 174.00 & 0.00 & 789.00 & 0.00 & 0.00 & 193.70 & 982.70 \\
\hline & Central & 1108.18 & 359.58 & 0.00 & 1467.76 & 362.00 & 0.00 & 0.00 & 1829.76 \\
\hline & Subtotal & 1723.18 & 533.58 & 159.96 & 2416.72 & 362.00 & 1881.50 & 338.72 & 4998.94 \\
\hline
\end{tabular}

Source: Central Electricity Authority (CEA, 2017)

Out of the total installed capacity in Gujarat, nearly $27.12 \%$ belongs to the contribution of state-owned energy enterprises whereas it is nearly $43.73 \%$ in a state like Kerala. The contribution of private sector is only $19.66 \%$ in Kerala whereas it is accounted for nearly $60 \%$ in Gujarat. The central government contribution is only $13 \%$ for Gujarat while it is nearly $37 \%$ in Kerala. It is an irony to note that a state like Kerala which is the major recipient of unilateral payments from the rest of the world fails to attract investment in power generation which is vital for the state's development. The state is struggling to fulfill the requirements even though its per capita energy consumption is one of the lowest in India. The power generation in the state is uncertain and erratic to meet the demands due to its substantial dependence on hydro power generation. In thermal power generation also, the Central Government contribution is very high which is obvious from the data.

\subsection{Transport System}

Gujarat has been getting considerable attention within the nation as well as from the rest of the world in connection with the rate of industrial growth and infrastructure development during the last two decades. It is considered to be a state with a lively economy and has been mentioned 
A comparative study of economic development of Gujarat and Kerala (A study with special reference to the role of infrastructure in economic development)

in various studies and literature development in connection with a range of political, social and economic issues. Located on the western shores of India, Gujarat has shown dynamic changes in association with the urbanization as well as developing linkage with the other parts of the country through a network of highways, roads streets, air and ocean courses. Of late, the state has adopted its plan to have green urban mobility and public transport networking system that provides multiple transport options to the public also (GIDB, 2018). There are 17 national expressways with aggregate length of $4032 \mathrm{~km}$ and more than 300 state roadways with aggregate length of 19,761 km (GIDB, 2017). Gujarat State has the longest ocean shore of 1600 $\mathrm{km}$ in India (Morris, 2012) that comprises of 33\% of the country's beachfront restrain. The major sea ports in the state of Gujarat such as Navlakhi, Magdalla, Pipavav, Porbandar, Veraval are the prime centers of export and import of goods in domestic and international logistics process. In air freights, Gujarat has seventeen air terminals. The Gujarat Civil Aviation Board (GUJCAB) has been shaped to cultivate advancement of flight framework in Gujarat. Universal air terminal at Ahmadabad and ten different air terminals are utilized for residential transport network within the state. The implementation of GST system has supported the movement of logistics through the transport networking system in the state by removing various hurdles and bottlenecks.

According to Economic Review (2010-2017), the state of Kerala has eight National Highways which keep running for around $1457 \mathrm{~km}$ and the total internal road length is 31812 $\mathrm{kms}$. The length of railway route is $1588 \mathrm{kms}$ and its coastline is of around $590 \mathrm{kms}$ and there are 17 intermediate $\&$ minor ports in the state among which the most important port is Cochin port which is under the control of the Central Government. All the middle and minor ports are managed by the Government of Kerala. All the ports assist the merchandise and transportation of goods for logistics. In air transportation, Kerala has universal airplane terminals in Thiruvananthapuram, Kozhikode, Kochi and Kannur that accommodate more than 10 million passengers now. The total number of flights operated is 95790 . The total movement of air freight and sea freight is relatively low as compared to the state of Gujarat due to various factors such as slow industrial growth, competition from nearby ports, labor problems etc. (Economic Review, 2016).

\section{IMPACT OF POWER AND ROAD DEVELOPMENT ON ECONOMIC GROWTH}

When considering the relationship between the NSDP and infrastructure development, the following trends are revealed from the data sourced from CSO during various decades ranging from 1981 till 2010. The table 10 and 11 shows the relationship between infrastructure development in the field of electricity and transport system with that of PCNSDP and the trend growth rates for the state of Gujarat and Kerala.

Table 10 Relationship between developments in electricity and transport system with the PCNSDP

\begin{tabular}{|c|c|c|c|c|c|c|c|c|c|}
\hline \multirow{2}{*}{ State } & \multicolumn{3}{|c|}{ PCNSDP (Rs) } & \multicolumn{3}{c|}{ *Electricity (kWh) } & \multicolumn{3}{c|}{$* *$ Road (Km) } \\
\cline { 2 - 10 } & $1981-90$ & $1991-' 00$ & $2001-10$ & $81-90$ & $91-00$ & $2001-10$ & $81-90$ & $91-2000$ & $2001-10$ \\
\hline Gujarat & 14637.70 & 22145.10 & 34743.20 & 298.30 & 643.90 & 1278.40 & 271.80 & 409.90 & 670.0 \\
\hline Kerala & 13474.80 & 19986.10 & 34022.60 & 127.60 & 235.0 & 419.30 & 670.60 & 1086.60 & 2482.40 \\
\hline
\end{tabular}

- Source: Central Statistical Organization (1981-2010).

- *Electricity: $\mathrm{kWh}$ per capita 
- $\quad * *$ Road: Kms of surfaced road per 1000 sq. km of geographical area

Table 11 Trend growth rate of PCNSDP and infrastructure variables in Kerala and Gujarat

\begin{tabular}{|c|c|c|c|c|c|c|c|c|c|}
\hline \multirow{2}{*}{ State } & \multicolumn{3}{|c|}{ PCNSDP (\%) } & \multicolumn{3}{c|}{ Electricity (\%) } & \multicolumn{3}{c|}{ Road (\%) } \\
\cline { 2 - 11 } & $\begin{array}{c}1981- \\
90\end{array}$ & $\begin{array}{c}1991- \\
2000\end{array}$ & $2001-10$ & $81-90$ & $91-00$ & $2001-10$ & $81-90$ & $91-2000$ & $2001-10$ \\
\hline Gujarat & 2.77 & 6.00 & 8.53 & 7.42 & 6.56 & 5.83 & 6.16 & 4.51 & 1.23 \\
\hline Kerala & 1.14 & 4.83 & 7.16 & 4.45 & 4.87 & 3.58 & 3.62 & 3.19 & 10.04 \\
\hline & & & & & & & & & \\
\hline
\end{tabular}

Source: CSO Data (1981-2010)

The economic variable that is applied to measure economic growth is the Per Capita Net State Domestic Product (PCNSDP) with that of physical variables such as power generation and road density. The power generation is measured by per capita electricity consumption $(\mathrm{KwH})$ and the road density is measured by $\mathrm{km}$ of surfaced road per 1000 sq.km of geographical area. The state of Gujarat had high level of infrastructure availability in the beginning of 198081 and it continued to develop it as electricity consumption increased by $7.4 \%$ in 1981-90. The consumption rate was more or less nearly $5 \%$ throughout from 1990s to 2000 . In the case of road density, Gujarat recorded high growth rate during 1981-90 but later is got reduced to $4.51 \%$ and $1.23 \%$ during the next decades respectively. Kerala recorded highest growth rate in road density during 2001-2010, even though it was lagging behind Gujarat during the first two decades. In the case of total road density also, Kerala has been consistently recorded higher density than Gujarat throughout the three decades beginning from 1981 onwards.

From the above analysis, it is obvious that infrastructural variables such as power and transportation play a pivotal role in the development of states such as Gujarat and Kerala. A recent study conducted by NCAER (2017), reveals the following trend in overall infrastructural facilities in both the states.

Table 12 A general comparison of the total infrastructure development in Gujarat and Kerala

\begin{tabular}{|c|c|c|c|c|c|}
\hline \multirow{2}{*}{ SI No. } & Infrastructure & \multicolumn{2}{|c|}{ Gujarat } & \multicolumn{3}{c|}{ Kerala } \\
\cline { 2 - 6 } & & Rating \% & Ranking & Rating\% & Ranking \\
\hline 1 & Infrastructure Overall & 32.5 & 8 & 36.9 & 5 \\
\hline 2 & Power Shortage as \% of Demand & 100 & 1 & 94.4 & 11 \\
\hline 3 & ICT - Readiness Index & 76 & 4 & 73.6 & 6 \\
\hline 4 & Average Tariff for Industry & 45.7 & 14 & 56.9 & 9 \\
\hline 5 & Bank Branches Per Lakh Population & 38.2 & 11 & 56.5 & 7 \\
\hline 6 & Groundwater Withdrawal by Industries & 35.6 & 6 & 39.9 & 2 \\
\hline 7 & Groundwater Availability & 20.1 & 15 & 29.9 & 8 \\
\hline 8 & Rail Density & 18.2 & 11 & 18.3 & 10 \\
\hline
\end{tabular}


A comparative study of economic development of Gujarat and Kerala (A study with special reference to the role of infrastructure in economic development)

\begin{tabular}{|c|c|c|c|c|c|}
\hline \multirow{2}{*}{ SI No. } & Infrastructure & \multicolumn{2}{|c|}{ Gujarat } & \multicolumn{3}{c|}{ Kerala } \\
\cline { 3 - 6 } & & Rating \% & Ranking & Rating\% & Ranking \\
\hline 9 & Cargo Handled Per Day in Airports & 9.8 & 8 & 12.9 & 7 \\
\hline 10 & Statutory towns as \% of the state & 6 & 6 & 1.7 & 17 \\
\hline 11 & Road Density & 1.8 & 18 & 0.1 & 8 \\
\hline 12 & Cargo Handled Per Port & 1 & 1 & 0 & 17 \\
\hline
\end{tabular}

Source: National Council of Applied Economic Research, SIPI, Third Edition 2018.

\section{FINDINGS OF THE STUDY}

1. Throughout the analysis, it is found that there exists positive correlation between infrastructure in the form of electricity and roadways on per capita domestic product. During the initial decades, it is found that the relationship was such that 1 percentage increase in electricity consumption leads to $0.14 \%$ increase in domestic output. In the case of road transport system, it was found to be negligent to the extent of $0.09 \%$. This trend is visible throughout the other two decades also.

2. In the case of Gujarat, the impact of increase in state NSDP on PCNSDP should be high, but it got regressed due to the higher rate of increase in population growth which has been a crucial factor in determining the PCNSDP. Kerala shows higher ranking in per capital output not because of higher rate of increase in gross domestic product but due to the slower rate of population growth as the state has always recorded a lower growth rate (Table 3) during the period under consideration.

3. The increase in PCNSDP in Kerala from 1981-2015 has been found to be the result of foreign remittances. In 1980-81, the foreign remittance was around 348.24 crores of rupees which later increased to 43152 crores of rupees in 2010. According to latest statistics, the remittance forms nearly more than $30 \%$ of the GDP of the state during 2017 (CDS, 2017).

4. Unilateral remittance by expats to Kerala is a major source of income to the state which is accounted for nearly $31.2 \%$ of the total GDP of the state. This is one of the unique factors that differentiate the state from that of Gujarat. It is a fact that Gujarat has been receiving FDI flow, but not equal to the amount received by Kerala through expat remittance. The advantage of Gujarat is that the FDI generates income and development to the economy which can be considered to be sustainable and out of the total FDI received by Gujarat, one of the routes of investment is infrastructure. Gujarat received an FDI flow of \$1001 million during the year 2011-2012. For the state of Kerala, the figure is \$ 471 million (DIPP, 2012). Kerala gets FDI flow which is primarily channelized towards the service sectors. The manufacturing sector shows regressed growth throughout the period of analysis. This factor is quite threatening in the sense that the employment generation is very poor and industries are shying away from engaging in business activities in Kerala mainly due to the harsh and hostile approach of the trade unions.

\section{CONCLUSION}

The model of growth followed by Gujarat and Kerala has got its own uniqueness due to the differences in the component of economic variables that constitute the elements of economic 
growth. Gujarat is one of the leading states where the economic growth rate is very high and the various components of state output is generated by giving due importance to primary sector, secondary sector and the tertiary sector. Hence the model is sustainable due to its focus on improvement of capability enhancing variables through sound investment plans that encompasses all the sectors of the economy. The state has proved it through its growth in manufacturing and service sectors by attracting investment within the country as well as from outside the country. The Gujarat model gives emphasis to the hard-infrastructural variables for maintaining and promoting the growth momentum. The Kerala model of growth relies more on social changes which is supposed to trigger off rapid momentum of growth in various spheres of activity. Various studies reveal that Kerala ranks high in various soft infrastructure indicators. But it is a fact that there are various areas where the state is lagging behind the national average, even though it is rated very high in social indices. The state needs to focus on developing agriculture and manufacturing so as to enable it to develop strong basis for sustainable development in future.

\section{REFERENCE}

[1] Ahluwalia, M S, State-level Performance under Economic Reforms in India, Planning Commission, Government of India, New Delhi, 2007

[2] Ajit Kumar Senapati, P.C.Mishra, B.C.Routra and Amitabha Biswas, "An Extensive Literature Review on Lead Time Reduction in Inventory Control" International Journal of Engineering and Advanced Technology (IJEAT), Vol.1, Issue-6, August, 2012

[3] Amin, S, Four comments on Kerala, Monthly Review, Vol.42 (8), 28, 1991

[4] Ann Verhetsel, Roselinde Kessels, Peter Goos, Toon Zijlstra, Nele Blomme, Jeroen Cant, "Location of logistics companies: a stated preference study to disentangle the impact of accessibility" Journal of Transport Geography, Vol.42, 2015, pp.110-121.

[5] Bhagwathi, J. \& Panagariya, A, India Reforms, Oxford University Press, ISBN: 9780199915187, 2012

[6] Bhagwathi, J, Gujarat promises continued, accelerated and all-round development. Retrieved-fromhttp://articles.economictimes.indiatimes.com/2013-01

02/news/36111596_1_keralamodel-gujarat-model-social-indicators, 2013

[7] Bhalla, G. S and Singh, G, 'Recent Development in Indian Agriculture: A State Level Analysis', Economic and Political Weekly, Vol. 32, No 13, 1997, pp A-2 - A-18.

[8] Chandrasekhar, C.P, "Trends and Patterns in Industrial Growth: A Review", in C P Chandrasekhar edited, Indian Industrialization, Volume 1: ICSSR Research Surveys and Explorations in Economics, Oxford University Press, New Delhi, 2015.

[9] DIPP (Department of Industrial Policy and Promotion, Retrieved from https://dipp.gov.in/acts-and-rules/notifications/paper, 2012

[10] Directorate of Economics \& Statistics, Socio Economic Review 2015, Budget Publication No.34, Government of Gujarat, 2015

[11] Estache, A. and Wren-Lewis, "Toward a Theory of Regulation for Developing Countries: Following Jean Jacques Laffont's Lead," Journal of Economic Literature, 47:3, 2009, pp 730-771. 
A comparative study of economic development of Gujarat and Kerala (A study with special reference to the role of infrastructure in economic development)

[12] Fedderke, J.W., Perkins, P. and Luiz, J.M, "Infrastructural Investment in Long-run Economic Growth: South Africa 1875-2001". World Development 34(6), 2006, PP, 1037.1059

[13] Franke, R. W., \& Chasin, B. H, Kerala: Development through radical reforms. New Delhi: Promilla, 1994

[14] Franke, R. W., \& Chasin, B. H, Power to the Malayalee People, Economic and Political Weekly, Vol. 32(48), 1997, pp 3061-3068.

[15] G.Vaidyanathan, " Current Status of Logistics in India" PIANC Magazine n $13{ }^{\circ} 126$, February 2007.

[16] Hirway, I, 'Selective Development and Widening Disparities in Gujarat', Economic and Political Weekly, Vol. 30, Nos. 41 and 42, 1995, pp 2603-18.

[17] IREDA (Indian Renewable Energy Development Agency, IREDA-JICA Half Yearly Newsletter, January 2017.

[18] ISID (Institute for Studies in Industrial Development), Retrieved from http://www.isid.org.in/home.html, 2017

[19] Ismail Karayun, Halil Ibrahim Aydin and Mustafa Gulmez, "The role of logistics in Regional Development" Annals of the Constantin Brancusi, University of Targu Jiu, Economy Series, Issue 4, 2012

[20] Jeffrey D. Sachs, Nirupam Bajpai, Ananthi Ramiah, “Understanding Regional Economic Growth in India" Paper prepared for the Asian Economic Panel meeting to be held in Seoul on October 25-26, 2001.

[21] K. K. Subrahmanian \& E. Abdul Azeez, Industrial Growth in Kerala: Trends and explanations" Working Paper No. 310, November, 2000

[22] KSPB (Kerala State Planning Board), Kerala State Planning Board, Government of Kerala, Retrieved from http://spb.kerala.gov.in/, 2016

[23] Kundu, A, 'Globalizing Gujarat-Urbanization, Employment and Poverty', Economic and Political Weekly, Vol. 35, Nos. 35-36, 2000, pp 3172-81

[24] Morris, D. M., \& McAlpin, M. B, Measuring the condition of India's poor: The physical quality of life index. $6^{\text {th }}$ Edition, New Delhi: Promilla.1982

[25] Mundle, S., P. Chakrabaorty, S. Chowdhury and S Sikdar, The Quality of Governance: How have Indian States Performed, Economic and Political Weekly of India, Vol. XLVII, No.49, 2012, pp 41-51.

[26] Nagaraj, R, "Economic Growth, Inequality and Social Development in India - Is Inclusive Growth Possible?" United Nations Research Institute for Social Development (UNRISD), Geneva, Palgrave Macmillan, London 2012.

[27] NCAER (National Council of Applied Economic Research), SIPI, Third Edition 2018.

[28] Pankaj Chandra, Nimit Jain, "The Logistics Sector in India: Overview and Challenges" Indian Institute of Management, W.P. No.2007-03-07. 
[29] Patra, A. and Acharya, A, Regional disparity, infrastructure development and economic growth: An interstate analysis. Research and Practice in Social Sciences, 6 (2), 2011, pp $17-30$

[30] Pinar Hayaloglu, "The Impact of Developments in the Logistics Sector on Economic Growth: The Case of OECD Countries", International Journal of Economics and Financial, Issues 5(2), 2015, pp. 523-530.

[31] RatcliRe, J.W, Social Justice and Demographic Transition: Lessons from India's Kerala State, International Journal of Health, 8(1), 1978, pp 123-144

[32] Rene Veron, "The New Kerala Model": Lessons for sustainable development, World Development, Elsevier Science Ltd.,Vol. 29. No.4, 2001, pp 601-617

[33] SPB (State Planning Board, Kerala), Economic Review 2016-2017, 2016

[34] Toman, Michael A., and Barbora Jemelkova, "Energy and Economic Development: An Assessment of the State of Knowledge." Energy Journal 24(4), 2003, pp 93-112.

[35] Van Ruijven B, Urban F, Benders RMJ, Moll HC, Van Der Sluijs JP, De Vries B, Van Vuuren DP, Modeling energy and development: an evaluation of models and concepts. World Development 36(12), 2008, pp 2801

[36] World Bank, “Global Real GDP Growth”, World Bank, Global Economic Prospects, June 2018.

[37] World Population Review, Retrieved from http://worldpopulationreview.com/, 2019, 2017

[38] Wout Dullaert, Luca Zamparini, "The impact of lead time reliability in freight transport: A logistics assessment of transport economics findings" Transportation Research, Vol. 4, 2013, pp. 190-200.

[39] Yasheng Huang, Soft vis-à-vis Hard Infrastructures for Economic Growth: Can China Learn from India? Sloan School of Management, MIT Author of Selling China (Cambridge University Press 2003), 2003 